\title{
Geographical Variation in Local Gender Contracts in Sweden
}

\author{
Karen Haandrikman ${ }^{1,2}$ (D) $\cdot$ Natasha A. Webster ${ }^{1}$ (D) $\cdot$ Ann-Zofie Duvander ${ }^{3}$ (D)
}

Received: 4 June 2020 / Accepted: 23 November 2020/Published online: 28 January 2021

(C) The Author(s) 2021

\begin{abstract}
Despite Sweden's national gender-neutral family and social policies, local differences in gender contracts exist and have been related to differences in the structure of the labour market and cultural traditions. Existing studies are outdated and used relatively large administratively defined areas, which may lead to several measurement and interpretation errors. This paper examines geographical variation in gender contracts in present-day Sweden using individualized neighbourhoods on different scales. Gender contracts are operationalized using six indicators on the level of family, politics and labour. We identify five types of local gender contracts: the metropolitan gender contract, the progressive gender contract, the suburban gender contract, the commuter gender contract and the traditional gender contract. The most gender equal patterns are found in metropolitan and other urban areas, with high shares of fathers taking parental leave and the highest shares of women with high education and gainful employment, and low shares of young mothers. The analyses give evidence of considerable local variation instead of a dominant gender contract in each region. The findings may stimulate further research and local policies on gender inequality.
\end{abstract}

Keywords Gender contract · Family policy · Parental leave · Individualized neighbourhoods $\cdot$ Multiscalar approach

\section{Introduction}

Sweden has one of the highest levels of gender equality in the world. As early as the1960s, an "equality contract" emerged in Sweden (Duncan 1994; Hirdman 1990),

Karen Haandrikman

karen.haandrikman@humangeo.su.se

1 Department of Human Geography, Stockholm University, Stockholm, Sweden

2 Department of Social and Economic Geography, Uppsala University, Uppsala, Sweden

3 Stockholm University Demography Unit, Stockholm University, Stockholm, Sweden 
indicating that all adults should be economically independent and be able to do salaried work and care for children. Since then, the country has consistently been in the top-5 of gender equality rankings. In contrast to for instance southern Europe, Swedish policies have emphasized the sharing of both political and economic power as well as family responsibilities between men and women (Almqvist et al. 2010; Forsberg et al. 2000).

Gender contract is originally a theoretical concept, defined as the outcomes of negotiations between men and women on issues like labour, family and power (Hirdman 1988, 1992, 1993). Gender contracts represent the ways power negotiations over work and home practices, in a household, translate into a broader set of gendered societal 'contracts'. Using the concept of gender contract is useful as it can place gender into context, and in this case a specific locational context, that is, gender is spatial. Geographical differences in gender contracts emerge from the combination of the overall structure of gender relations: the way these are arranged within local labour market conditions, in the demographic structure, in history and in cultural traditions.

The spatial differences in gender equality and gender contracts were a topic of discussion in the 1990s, when a group of researchers linked gender contracts to specific places (Duncan 1994, 2000; Duncan and Pfau-Effinger 2000). In Sweden, geographical differences in gender relations were associated with local-historical conditions and national ideologies, based on data from the 1980s to 2001 (Forsberg 1998, 2010). Gender contracts have been operationalized in a variety of ways, mostly using qualitative or mixed methods but a few studies have conducted quantitative investigations. Forsberg (1998) compared municipal census data for the year 1990, while Amcoff (2001) used administrative data from the 1980s to 2001. Both showed evidence of a north-south divide, with more equal municipalities in the north and more unequal areas in the south. The most recent study, Forsberg (2010), using Amcoff's (2001) classification, found geographically dispersed gender contracts, which were labelled as the metropolitan gender contract, the family-oriented small-scale gender contract, the company-based gender contract, the agro-industrial gender contract, and the northern light gender contract.

The main motivation for the current paper is to update these studies with newer and stronger data and improved methods, as the Amcoff (2001) study indicated that the study was particularly limited by the data and the relatively crude aggregation into geographical areas at hand. In recent decades, geographically coded data have become increasingly available to researchers. Updating the studies provides insights to the ways Sweden, and other countries are changing.

Almost 40 years have passed since some of the data used in the first study mapping local gender contracts (Forsberg 1998), and Sweden has changed in that time period. More people live in urban areas now, and the labour market has changed considerably (Korpi and Thålin 2011; Gottfries 2018). Employment in the service sector continues to grow at the expense jobs in the industry sector. Unemployment levels are much higher than in the 1980s, though levels are lower than the EU average. Overall, wages have increased, especially in the private sector. Women's wages are catching up, women's labour force participation is close to that of men and the gender wage gap has decreased. Migration to Sweden has increased substantially, and migrants take longer to find work, especially among women and refugees and their families. A second group doing more poorly in the labour market are those with lower education, and they are overrepresented in rural areas. Last but not least, family policies and other policies 
affecting work-life balance have changed in the last decades. There has been an increase in the parental leave days fathers take, and an increase in the share of couples dividing the leave equally (Duvander and Löfgren 2020). Gender contracts are still prevalent but a contemporary perspective illustrates changing gender roles in parallel with larger societal changes.

This paper uses geocoded register data on the whole Swedish population from 2010, containing a wide range of demographic and socio-economic variables. Its excellent geographic attributes enable a spatial study with much geographical detail, as it has location coordinates of each 100 by $100-\mathrm{m}$ square for each registered person. The aim of this paper is, following up on earlier studies, to identify geographical variations of gender contracts in present-day Sweden using individualized neighbourhoods. Our research questions are 1) What does the geographical distribution of factors contributing to local gender contracts look like in present-day Sweden? and 2) To what extent do local gender contracts cluster geographically when using small-scale individualized neighbourhoods?

Increased availability of improved data has also led to innovative methods in the field of segregation and neighbourhood effects. Creating bespoke or individualized neighbourhoods is one such method, where neighbourhoods are defined by every resident's nearest neighbours, instead of administratively defined areas. A first advantage compared to traditional spatial analysis is that when using individualized neighbourhoods, we no longer depend on administrative borders, which may lead to issues summarized as the Modifiable Area Unit Problem (Openshaw 1984). Second, social interaction in the neighbourhood may be captured better, resulting in a better representation of how neighbourhoods are perceived by residents (Kwan 2012; Nielsen and Hennerdal 2017). Third, the use of individualized neighbourhoods allows for the measurement of different types of indicators on different scales. Throughout Forsberg's work, we can see a shift from the regional the local scale level; reflecting that the local level is where gender contracts are constructed. With a multiscalar methodology, the size of the neighbourhood can vary, which is important when the most appropriate scale level is unknown, and is preferred over uniscalar studies (Fisher et al. 2004; Hennerdal and Nielsen 2017).

We operationalize gender contracts using six different indicators on the levels of family, labour and politics. Our main indicator is fathers' share of parental leave use, which is a common indicator of gender equality in Sweden used by government authorities (Swedish Social Insurance Agency 2018). It is often assumed that an equal division of parental leave will lead to other changes in the direction of gender equality (Duvander et al. 2015). For instance, reforms to reserve leave days for fathers were introduced in Sweden in 1995, anticipating that fathers' increased leave would lead to increased gender equality in the labour market and in the homes (Duvander and Johansson 2012). Parental leave in Sweden is available on a national level to all parents, but local use varies. Childcare availability is a local condition that may shape the gender contract, though local availability is not a problem (Nyberg 2007). Local variation in father's share of parental leave is the result of gendered negotiations in who takes the leave. Knowledge about local variation in father's share of parental leave therefore provides us with an increased understanding of the geographical variation in how social policies are used by men and women. Results of the study may inform national and local policy makers seeking to 
address gendered parental leave and other gender inequalities, by showing the extent of variation in gender equality across areas.

After a short introduction to the concept of gender contracts, we give an overview of previous studies that have operationalized gender contracts in a geographical way. The data and methods sections describes the full-population data we use in the paper, the methods we use to define areas and to conduct a spatial analysis. The first part of the results analyses the geographical distribution of father's share of parental leave and other indicators of gender contracts, and the second part shows the results of a cluster analysis of local gender contracts. The last section concludes and discusses findings in the light of previous studies.

\section{An Introduction to Gender Contracts}

The concept gender contract derives from the historian Yvonne Hirdman's (1992, 1993) work examining how gender systems, divided into spheres of female and male, results in patterns of negotiated behaviour, or contracts, within households. Gender contract theory emerged within the context of the Scandinavian universalistic welfare state where governments had committed themselves to gender equality and women-friendly reforms and initiatives (Duncan 1995). Thus, with the rise of strong welfare policies, gendered negotiations should more or less be minimized. However, as studies operationalizing gender contract theory have shown, the picture is much more complex (see e.g. Forsberg 1998, 2010; Amcoff 2001).

A gender contract refers to "social agreements on what men and women are, what they think and expect, and what they do" (Duncan 1995: 265). The term 'contract' may seem to imply that there is a formalized agreement between equal parties with set outcomes; but this was not Hirdman's intention. Instead, she refers to the etymological meaning of the word, which is "pulling two things together" (Hirdman 1992:10). Gender contracts have also been defined as "informal understandings and agreements over the way people carry out their daily lives" (Forsberg et al. 2000: 42 based on Åström and Hirdman 1992). Gender contracts are versions of the larger compromises between men and women regarding divisions of labour, family and power. According to Hirdman, gender contracts are present in all levels of the gender system: the metaphysical, the institutional and the individual level. That is, certain perceptions and expectations about the relationship between men and women (metaphysical level); institutionalized forms of gender differences and divisions of labour (institutional level); and specific contracts between individual men and women (individual level), all contribute to the construction of a gender contract. Gender contracts include all forms of work, including household work, decision-making, family relations, and even dynamics in local politics, in a non-uniform way.

Changes in gender contracts may reflect fluctuating relations between the metaphysical, institutional and individual level. Processes of conflict, negotiation and renegotiation may reshape gender contracts over time (Forsberg 2010). Thus, gender contracts reveal the ways in which ongoing unequal divisions of labour between men and women are constructed, internalized and how norms within gender-based power structures or systems shift over time. For policy makers, changing gender contracts can indicate 
local responses to shifting or newly introduced policies or initiatives. By monitoring gender contracts there is potential for incremental change.

While gender contracts are theoretically and methodically challenging, they potentially offer policy makers insights into the processes of inequalities between genders at the regional or local level. Gender contacts present a means to connect the seemingly informal realm of individual choices and actions (a gender contract) to the larger institutional and structural forces. When coupled with spatial contexts - regions or neighbourhoods - the potential to provide geographically nuanced understandings, gender contract theory may give insights to the social-economic factors shaping local responses to policy initiatives.

\section{Previous Studies on Geographical Patterns of Gender Contracts}

The study of local gender contracts, where gender contracts are linked to specific places, has its beginnings in a network of researchers examining gender inequality in European regions, in the 1990s (Duncan 1994, 2000; Duncan and Pfau-Effinger 2000). These studies theorized differences in gender relations and started to examine the regional and local contexts of gender inequality. In general, they stated that the form and degree of gender inequality together with its origins and consequences differ substantially over time and place. In countries such as the United Kingdom (McDowell and Massey 1984), Finland and West Germany (Pfau-Effinger 1994), and Sweden (Forsberg 1998, 2010), it was found that gender relations were associated with both local-historical conditions and national ideologies. A recent study in the US found that local patterns of gender norms are sustained through contextual effects (Scarborough and Sin 2020).

These ideas are grounded in how different gender welfare regimes have led to different positions of men and women in different places (Duncan 1995). The work of Esping-Andersen (1990) is important in this respect, examining spatial differences in welfare policies and how the different effects of those policies on women and men are understood and analysed. Pfau-Effinger (1994) added that welfare policies are also historically rooted in country-specific cultural norms about gender, work and family life. Walby's interpretation of patriarchy (Walby 1990; Walby 1994) also provides a point of departure for the spatial differences in gender relations, distinguishing between different patriarchal structures, which play out differently in different contexts and spatially across contexts. Common to these studies is an emphasis on the need to improve localized understanding of the diversity of gendered relations within a gender system.

That gender contracts are shaped by spaces and places has been examined in Sweden in a number of studies (Amcoff 2001; Forsberg 1997, 1998, 2001, 2010; Forsberg and Stenbacka 2017; Forsberg et al. 2006; Gil Solá 2016; Hedfeldt 2008; Stenbacka et al. 2018; Forsberg and Lindgren 2015; Webster and Caretta 2016). A majority of these studies have used either qualitative or mixed methods, using case studies within Sweden, mostly in rural areas. The only studies mapping gender contracts for the whole of Sweden are Forsberg (1998, 2010) and Amcoff (2001), using a range of regional statistical indicators to operationalize gender contracts. Using regional political, economic, social and demographic indicators from census data, 
labour force survey data and electoral statistics for the years 1980, 1985 and 1990, Forsberg (Forsberg 1997;Forsberg 1998 ${ }^{1}$ ) describes regional differences in gender contracts, that are not based on all Swedish regions, but "on epitomous areas" (Forsberg 1998; p. 203), and is not based on fixed regions. Unfortunately, she neither shows the actual regional statistics, maps or accounts for the methods used to cluster regions. She distinguished between three gender contracts: traditional, modernized and non-traditional gender contracts. Traditional gender contracts are characterized by a segregated labour market based on the male breadwinner model. In regions with modernized contracts, labour market segregation was less pronounced as were income differences between men and women. In regions undergoing economic transformation and substantial in-migration, the so-called non-traditional gender contract was described as an in-between contract. Forsberg described a north-south divide with more equal municipalities in the north and more unequal municipalities in the south.

Amcoff (2001) building on Forsberg's (1998) work in an unpublished paper, conducted a cluster analysis on data grouped in municipalities and local insurance agency areas with data covering the 1980s to 2001, finding quite similar patterns. Regional variation in female participation in local politics, educational level, the wage gap, employment rates, the share of fathers taking parental leave, fertility among young women, and the percentage of women among the unmarried and divorced population were included in the analysis. Five gender contracts were suggested: the modernistic, the traditional, the middle non-traditional, the individual non-traditional, and the "Norrland contract". The majority of the five identified clusters are geographically dispersed. The most important difference with Forsberg's (1998) clusters is the separate Norrland cluster; otherwise the clusters seem to have remained stable over time since Forsberg's (1998) study. Forsberg (2010) later described these five clusters using different labels, as described in the following. Metropolitan gender contracts (like the modernistic contracts) were described by having high female involvement in politics as well as high levels of female education and labour market participation. In such areas, found especially in metropolitan areas and larger towns, men's share of parental leave was among the lowest in the country, and men's incomes were substantially higher than women's. The family-oriented small-scale gender contract (relabelled from the traditional contract), found in inner parts of southern Sweden, is also typified by low shares of men's parental leave. Furthermore, it is characterized by low female participation in politics, and though women are higher educated than men, the gender income gap is substantial. Third, the company-based gender contract (the earlier middle non-traditional contract) is similar to the former, but here, men's parental leave uptake is higher. These gender contracts are found in old industrial iron ore areas in southern and central Sweden. Fourth, the agro-industrial gender contract (the earlier individual non-traditional contract) is in some ways similar to the second contract, but female political representation and the share of higher educated women was higher. Such contracts were found in agricultural and industrial municipalities along the northern and western coast. Finally, the fifth type was labelled as the northern light gender contract (the earlier Norrland contract) found in the northern inlands. These areas are quite equal in terms of men's and women's income levels, and in some of these areas, employment rates are higher for women than for men. Women are also

\footnotetext{
${ }^{1}$ The 1998 article is an English translation of the 1997 Swedish book chapter.
} 
better educated than men here, and have high grades of political participation; while men's parental leave uptake is low.

Several gender contracts may be in operation in one and the same region, according to Forsberg (2010), but she argues that in each region, one contract is dominant. The dominance of hegemonic regional gender contracts was debated by for instance Grimsrud (2011), who shows several gender contracts may co-exist in different spaces, and may chance because of migration. This implies that gender contracts are by no means static; they are constantly changing and responding to shifts in the three levels. Gender contracts influence and are influenced by norms and local cultures, resulting in geographical variation in the lives of men and women (Forsberg 2010). Gerrard (2017) found that traditional gender contracts in Norway's high north have been reworked in light of growing gendered mobility and changes within the fishing industry. Grubbström (2012) described changing gender contracts on the Estonian coast in a period of changing local place-based norms as a result of changes in livelihoods. In certain Swedish regions, gender contracts changed over time (Forsberg and Stenbacka 2013, 2017) and gender contracts vary locally within regions (Forsberg and Lindgren 2015). Sihto (2018) demonstrated that gender contracts may be changed because of local social policies regarding childcare in Finland. This demonstrates that significant metaphysical and institutional change could initiate rapid re-negotiations of established contracts.

Many of these studies had to work with limited data and sizable geographical units; using such units of measurement may be problematic. Their findings and limitations highlight the need for further and more detailed spatial analysis. Given Sweden's rapid social change, analyses with more recent data would enable a comparative view to these outdated studies. In the next section we explain how we operationalized gender contracts at detailed geographical levels.

\section{Data and Methods}

In order to examine geographical variation in gender contracts we used geocoded register data for the year 2010. We use a collection of register datasets compiled by Statistics Sweden, including all individuals registered in Sweden with a wide range of demographic, socioeconomic and geographic characteristics. Its excellent geographic attributes enable a spatial study with much geographical detail; the data has location coordinates of each 100 by 100 $\mathrm{m}$ square for each registered person.

The study uses individualized neighbourhoods, calculated with the software EquiPop, ${ }^{2}$ where we constructed individualized neighbourhoods with fixed population size. Each person has their own individualized neighbourhood, consisting of the closest people with certain characteristics, such as the 100 nearest higher educated women, or the 200 nearest fathers who take up parental leave. The method implies that while population size is fixed between neighbourhoods, the geographical size of those neighbourhoods varies, with larger neighbourhoods for less sparsely populated areas. Though population density varies throughout Sweden, the structure of neighbourhoods

\footnotetext{
${ }^{2}$ Developed by John Östh and freely available for non-commercial use through Uppsala University.
} 
is relatively similar. Andersson et al. (2018) show that half of the Swedish population has their closest 200 neighbours within $250 \mathrm{~m}$ from their house and $90 \%$ has their closest 200 neighbours within $1.5 \mathrm{~km}$. Distances to neighbours are much higher for higher k-levels.

Our research approach is to first map father's use of parental leave at different spatial scales. We use fathers' parental leave uptake as an indication of gender contracts, and the multiscalar analysis will suggest us the most appropriate geographical scale for measuring gender contracts. Scale is measured by varying the numbers of closest neighbours making up the individualized neighbourhoods; the nearest 12, 25, 50, 100, 200, 400, 800, 1600 and 3200 neighbours were included in the analysis. Second, we will continue with one scale level to map and analyse the geographical distribution of other indicators of gender contracts. Third, we use cluster analysis to discover and analyse geographical clusters of local gender contracts using the six indicators described below.

Similar to previous studies operationalizing local gender contracts quantitatively (Amcoff 2001; Forsberg 1998, 2010; Forsberg et al. 2006), and based on Walby's (1990; Walby 1994) dimensions of differentiated patriarchy, combined with the availability of data, we operationalized six indicators on three different levels: family, labour and politics.

On the level of politics, we measure men's share in parental leave uptake. Swedish parental leave for new-born children is gender neutral and consists of 8 months leave to each parent but it is common for fathers to transfer part of their days to the mother. In 2010, transfers could be made for all days, except for two months that were reserved for each parent. These are sometimes referred to as the "daddy quota". For the largest share of parental leave, the benefits received by parents reaches approximately $80 \%$ of the previous income, until a certain ceiling. There is significant flexibility in how to share and allocate the leave periods (Duvander and Viklund 2020). In 2010, parental leave could be used anytime up to the child turned 8 years old and it was commonplace to use leave over different periods. Mothers used about three quarters of all leave and there was a considerable part of about $20 \%$ of fathers not using any leave (Swedish Social Insurance Agency 2013). On average, fathers used about 100 days of parental leave.

The data available to us was a variable called "parental benefits" which included, besides parental leave, temporary parental benefits and child allowances. The variable is measured in income received from these three sources, in Swedish crowns. Temporary parental benefits are available to working parents and can be used if children are ill (so-called "vård av barn" - popularly referred to as "VAB"). Parents have 120 days per year to take care of their sick children until they are 12 years of age. Temporary parental benefits also include 10 days for fathers to be home with their newborn child, while the mother is home as well. Temporary benefits are paid at the same level as parental leave benefits, but with a somewhat lower ceiling. Childcare allowance is means-tested to care for sick children, usually with special needs, over a longer time period. The share of childcare allowance is small in the total amount of parental benefits received. For an overview of Swedish family policies see Swedish Social Insurance Agency (2018). 
For the purpose of the study, we created a variable measuring the share of the total income (income including parental leave benefits) that is spend on parental benefits ${ }^{3}$ for fathers with children aged 0-3 years. The age category was chosen as $80 \%$ of all fathers takes parental leave within the first two years of their child's life (Swedish Social Insurance Agency 2013). The majority (55\%) of men spends less than 5\% of their income on parental benefits, with $28 \%$ not taking any leave in $2010 .{ }^{4}$ For our analysis, we therefore chose a cut-off point of 5\%, e.g. we defined a dichotomous variable indicating whether fathers had spent more or less than $5 \%$ of their income on parental benefits. ${ }^{5}$ Spending less than $5 \%$ of one's income on parental benefits implies that not even the two months earmarked for the father are taken.

We conducted regression analyses to explain geographical variation in fathers' uptake of parental leave using different sets of variables in the domain of family and labour. Below we describe the indicators that were found most important in explaining the geographical variation (results available on request).

On the family level, two indicators were constructed following previous work on operationalizing gender contracts. First, we calculated the ratio of young mothers among young women and second, we included the ratio of single and divorced women among all single or divorced individuals. The first indicator was calculated as the share of women aged 15-24 with children, among the number of women aged 15-24. The second indicator was measured as the number of divorced and single women divided by the number of divorced and single persons. The motivation for including these indicators is that lower ages at childbearing are generally associated with more traditional views regarding relationships between men and women (Bernhard and Goldscheider 2006), in the light of the Second Demographic Transition (SDT). Areas with higher shares of young mothers might therefore be associated with more traditional views regarding gender equality. On the other hand, areas with a high share of divorced and single women might be a sign of increased gender equality, as women more often drive family dynamics such as divorce and cohabitation than men (Andersson et al. 2006; Brandén and Haandrikman 2018), and as we see an increase of single-person households in the course of the SDT.

Finally, on the level of labour, three variables were constructed. First, we included the share of women aged 25-64 with high income among the population aged 25-64, with high income defined as one standard deviation above the national average for women. Second, the ratio of highly educated women aged 18-64 divided by the number of higher educated men in the same age group was calculated. Third, an indicator was created measuring the ratio of gainfully employed women per the number of gainfully employed men, with gainful employment measured as earning at least the amount the Swedish Tax Office uses for the amount geared to the price index, 42,400 SEK in 2010. These variables were included as areas with high shares of women with high income, higher education and areas with relatively many gainfully employed women may be seen as areas with a higher gender equality.

\footnotetext{
${ }^{3}$ Parental leave benefits are normally almost $80 \%$ of the parent's income before the child's birth. There is a maximum to parental leave benefits so that those with high incomes can only receive benefits up to a certain level. In 2010 the income ceiling was 424,000 SEK.

${ }^{4}$ Among fathers not taking any leave, a substantial group has very high incomes.

${ }^{5}$ For fathers with incomes above the income ceiling, the income share was calculated as: parental leave benefits/ (parental leave benefits $+424,000$ ) * 100, using 424,000 SEK instead of their real income.
} 
A cluster analysis was performed using the indicators of gender contracts in order to reveal possible regional patterns of gender (in)equality and to discover whether geographical clusters on different scales can be identified that indicate local gender contracts. Cluster analysis is useful as it forms clusters of the 100 by $100 \mathrm{~m}$ squares that have similar features in the indicators studied. Indicators were selected based on results of several multivariate regressions, resulting in the six indicators mentioned above being the most suitable. K-means clustering was performed using different specifications - based on the large number of cases, k-means clustering is preferred over hierarchical clustering - resulting in an optimal solution of five clusters. In this procedure, cases (grids) are (re)assigned to the cluster for which the distance to the cluster means are smallest in several iterations. The resulting clusters have the smallest distances between cases and the largest possible distance between clusters.

\section{Results}

\section{Geographical Distribution of Father's Uptake of Parental Leave and Other Indicators of Gender Contracts}

We start our analysis with a multiscalar examination of the geographical distribution of a policy-level indicator of gender contracts: fathers' parental leave uptake, measured as the ratio of fathers of young children, whose parental benefits were at least $5 \%$ of their income divided by all fathers of young children. This indicates cases where households have used almost the two months earmarked for the father. We conducted a multiscalar analysis as beforehand it is unclear what the most suitable neighbourhood size is for examining gender contracts. The different maps in Fig. 1 represent nine different scale levels; showing the ratio when including different population sizes of fathers of young children in the neighbourhood or region. The first map shows the ratio taking into account fathers' parental leave uptake among the nearest 12 fathers with young children, the second among the nearest 25 , and so on, with the last map considering the 3200 nearest fathers with young children. The colour coding indicates quantiles of gendered parental leave use, with red indicating the highest shares of father's uptake of parental leave and blue indicating the lowest values. Seen over all grid cells in Sweden,

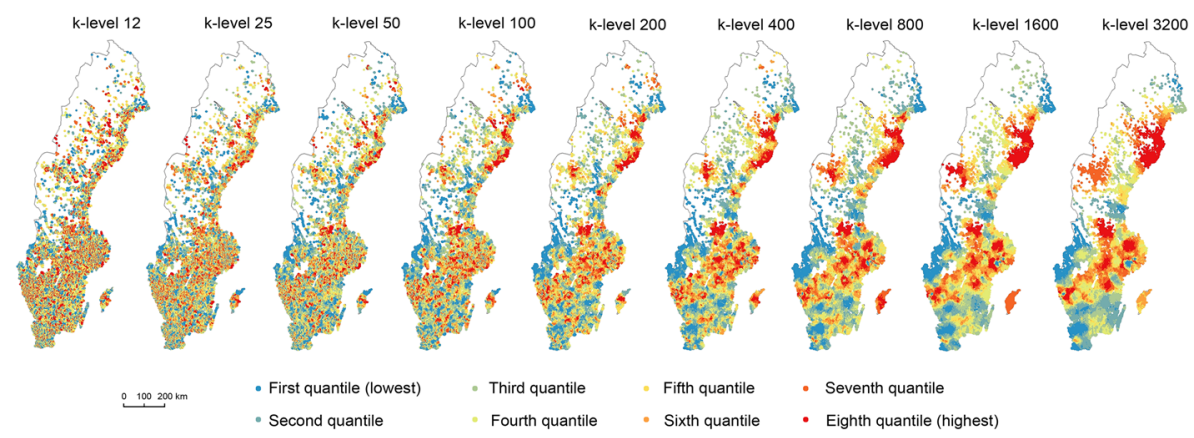

Fig. 1 Ratio of fathers of young children, whose parental benefits were at least $5 \%$ of their income per all fathers of young children, 2010, for different k-levels 
$38 \%$ of fathers took parental leave to an extent that the parental leave benefits made up at least $5 \%$ of their income (see Table 1 ).

We can make two general observations based on these maps. First, even though Sweden has nation-wide parental leave policies, there is large local geographical variation in men's share of parental leave uptake. Fathers' uptake of parental leave seems higher in urbanized areas but not only in such areas. There is some clustering of higher ratios in the area ranging from Stockholm at the east coast to the Gothenburg area at the west coast, together with a relatively large cluster of high ratios around Umeå and Skellefteå at the northern western coast. Around the southern part of the border with Norway, an area with relatively low uptake is visible. At higher scales, the south stands out as an area with relatively lower uptake throughout. Such clustering of gendered parental leave uptake is not very likely to be related to local differences availability of childcare (Nyberg 2007).

Second, these maps highlight the importance of scale in understanding local variation in parental leave uptake. Depending on what scale level is examined, the geographical pattern of parental leave uptake looks substantially different. At the lower scale levels, examining parental leave uptake among the 12 to 50 nearest fathers with young children, there is considerable local variation in father's share of parental leave uptake. As spatial variation is large at small scale levels, one should not choose geographical units that are very large, such as municipalities, as such regions may conceal a lot of dynamics that may otherwise remain unknown. If we zoom out and include several thousands of neighbours in the definition of neighbourhood, larger, rather homogenous clusters of fathers' parental leave uptake become visible. The multiscalar analysis shows that scale is a key factor in any geographical analysis and that choosing a scale level must be done with care, and should be based on the most appropriate scale level of the phenomenon under investigation. The patterns for fathers' share of parental leave starts to show increased clustering as of $k=200$. On smaller k-levels, clustering is hardly visible, and on higher k-levels, clustering may hide a lot of dynamics.

Figure 2 zooms in to one of the areas with relatively high uptake of parental leave among fathers: the county of Västerbotten in the north of Sweden. The inserted small map shows the location of the country within Sweden as well as the location of the coastal cities of Umeå and Skellefteå. In Forsberg's (2010) analysis, the municipality including Umeå, a university city, was classified as having a metropolitan gender contract. A small municipality on the west side of Umeå, Vännäs, had a company-

Table 1 Descriptive statistics on the six indicators of gender contracts, $k$-level 200, 2010

\begin{tabular}{llll}
\hline & Mean $\begin{array}{l}\text { Standard } \\
\text { deviation }\end{array}$ & $\begin{array}{l}\text { Number of } \\
\text { grid cells }\end{array}$ \\
\hline Share of fathers with parental leave benefits being at least 5\% of their income & 0.376 & 0.053 & 171,556 \\
Share of mothers among young women & 0.055 & 0.033 & 171,556 \\
Share of single and divorced women among single and divorced individuals & 0.468 & 0.043 & 171,556 \\
Share of women with high income among the working age population & 0.053 & 0.045 & 171,556 \\
Ratio of highly educated women among highly educated men & 1.103 & 0.248 & 171,556 \\
Share of gainfully employed women among gainfully employed men & 0.883 & 0.119 & 171,556 \\
\hline
\end{tabular}



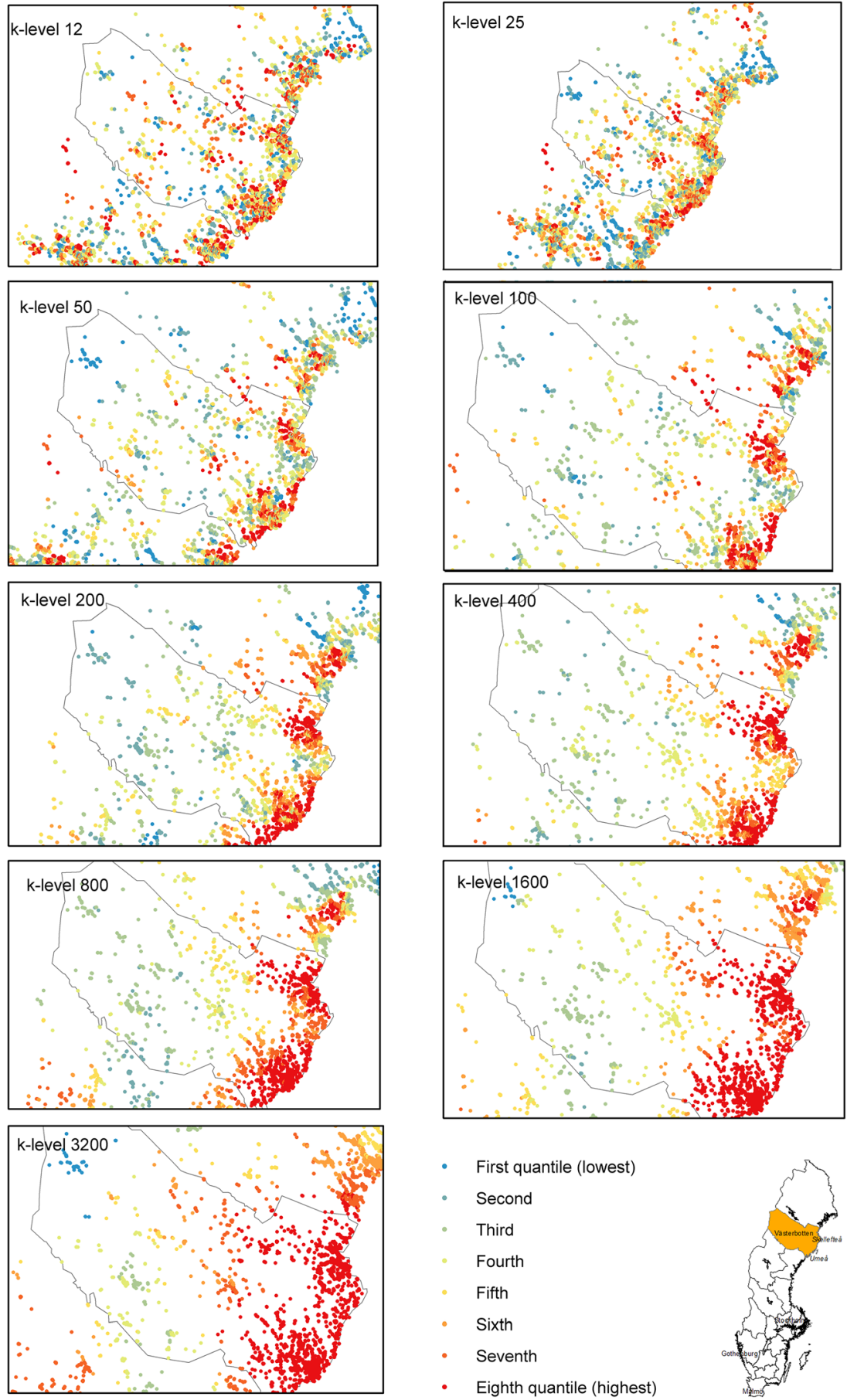

Fig. 2 Ratio of fathers of young children, whose parental benefits were at least $5 \%$ of their income per all fathers of young children, Västerbotten county 2010, for different k-levels 
based gender contract in that study. Skellefteå, a two hour-drive to the north of Umeå, is part of a large municipality that was classified as having an "agro-industrial gender contract". Figure 2 shows there is much more local variation, in fathers' uptake of parental leave, than the older municipal-based maps were able to reveal. There are quite many islands with very high parental leave uptake, even in the inland areas. At very high scale levels, the cluster size increases, and the maps show a decrease in fathers' parental leave uptake with increasing distance from the coast.

These multiscalar maps show that size matters. When interested in choosing an appropriate scale level for fathers' parental leave uptake, the maps in figs. 1 and 2 indicate that the scale level should not be too high neither too low to avoid either too much local variation or too homogeneous areas that hide local variation. For fathers and mothers who negotiate who takes what share of the assigned parental leave days, there seems to be some contextual effects; being surrounded by fathers taking leave to care for their children may have contagious effects. Indeed, the choice for the appropriate scale level depends on the research problem at hand. Studies using multiscalar approaches argue that different scales, so different sizes of nearest neighbours in an analysis, represent different social roles (Östh et al. 2015). For instance, if one is interested in the relation between neighbourhood unemployment and individual outcomes, it is likely that a relatively large neighbourhood scale would be appropriate, while when examining neighbourhood effects on taking a relatively longer parental leave period as a father may require a smaller scale level. Seeing other fathers with their young children on walks, in playgrounds or in playgroups in the neighbourhood may have larger effects on individual behaviour, compared to larger-scale regions. Studies on contextual effects have emphasized that spatial flexibility is to be preferred over choosing the "correct" neighbourhood scale (Sampson 2012; Malmberg et al. 2014). Based on a visual analysis of the maps in Figs. 1 and 2, together with the above reasoning about the appropriate level of examining neighbourhood influences on father's uptake of parental leave, a scale level of the nearest 200 fathers seems most appropriate and will be used for the remaining analyses, of what is most suitable for measuring local gender contracts.

We continue our analysis by examining the geographical distribution of five other indicators of local gender contracts, using individualized neighbourhoods and employing a $k$-level of 200 . Table 1 shows descriptive statistics on the six indicators. For $38 \%$ of fathers, their income from parental leave was at least $5 \%$ of their income in 2010; however, the maps in Fig. 1 have shown that this share varies across Sweden. When including the 200 nearest fathers with young children, the highest quantile (blue areas in the map) indicates ratios lower than $32 \%$, whereas the highest quantile (red areas in the map) includes shares between 44 and 58\%. Young women having children is quite a rare phenomenon in contemporary Sweden, while being single is quite common among women. Overall, the average share of women earning a high income is only $5 \%$ across areas, with high concentrations in metropolitan areas. In general, women are more often higher educated than men, and the maps have shown that this is quite common in many parts of Sweden. Table 1 shows that Sweden has a relatively large share of women being gainfully employed compared to the male workforce.

Figure 3 shows six maps of possible indicators of local gender contracts. The indicators are based on previous studies and represent family, labour and politics as different layers at which gender contracts are revealed. Each indicators takes into account the 200 nearest neighbours, as defined in the data and methods section. The 
colour coding is based on quantiles, with red indicating the highest values and blue indicating the lowest values. The maps show different aspects of gender contracts, and therefore a few display some spatial similarities while others are different. Particularly the indicator for women with high incomes seems to be associated to population density, with highest values in the metropolitan areas. The geographical distribution of young mothers is more even throughout the country. In general, the geographical patterns for the three labour indicators (maps $d$, $e$ and $f$ ) show some similarities. The share of highly educated women compared to highly educated men is fairly spread across all populated areas. All of these indicators indicate different aspects of gender relations and gender equality. Our next step is therefore to conduct a cluster analysis, in order to examine the clustering of different aspects of gender contracts.

\section{Local Gender Contracts}

A cluster analysis was performed using the six indicators of gender contracts in order to reveal possible regional patterns of gender (in)equality and to discover whether geographical clusters on different scales can be identified that indicate local gender contracts. Cluster analysis is useful as it forms clusters of the 100 by $100 \mathrm{~m}$ squares that have similar features in the six indicators studied.

Table 2 shows some descriptive statistics on the clusters, while fig. 4 displays the five different clusters that resulted from the cluster analysis in a map. A first observation is that this map of local gender contracts based on 2010 data and on individualized neighbourhoods based on 171,726 populated 100 by 100 m squares in Sweden looks quite different from the map with local gender contracts published by Forsberg (2010). The geographical distribution of local gender contract clusters is more varied, with each cluster type appearing in each part of the country. There is a very apparent geographical pattern, with urban areas often characterized by cluster 1 , that is surrounded by cluster 3 , which in turn is surrounded by cluster 2 , then cluster 5 and remaining areas are mostly cluster 4 areas.

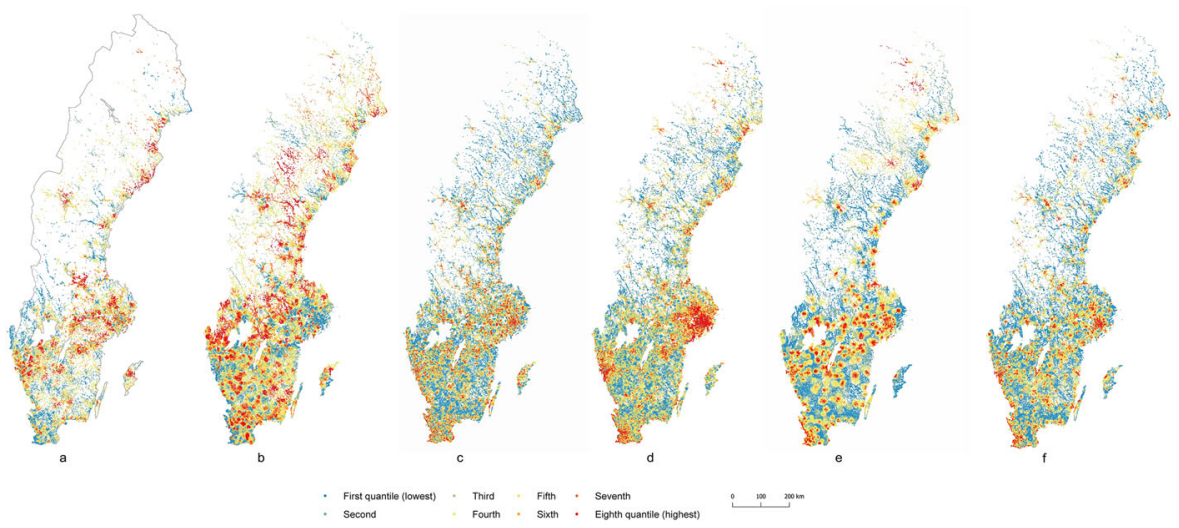

Fig. 3 Geographical distribution of indicators of local gender contracts, taking into account the 200 nearest neighbours. a. Share of fathers with parental leave benefits being at least $5 \%$ of their income, b. share of mothers among young women, c. share of single and divorced women among single and divorced individuals, d. share of women with high income among the working age population, e. share of highly educated women among highly educated men, f. share of gainfully employed women among gainfully employed men 


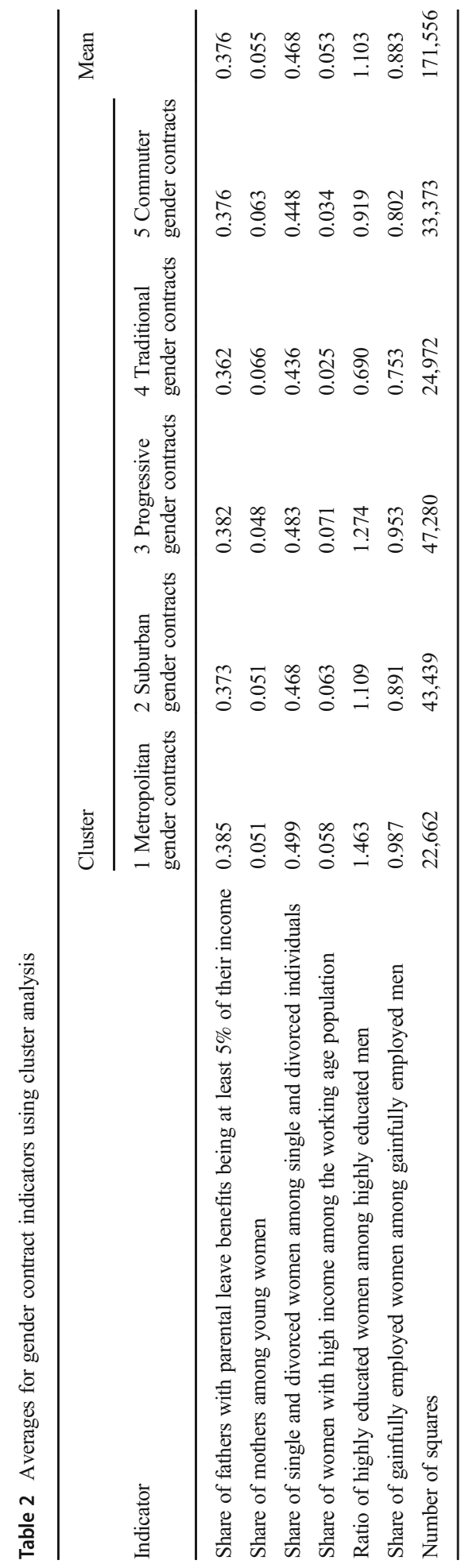




\section{Legend}

- metropolitan gender contract suburban gender contract

- progressive gender contract

- traditional gender contract

- commuter gender contract
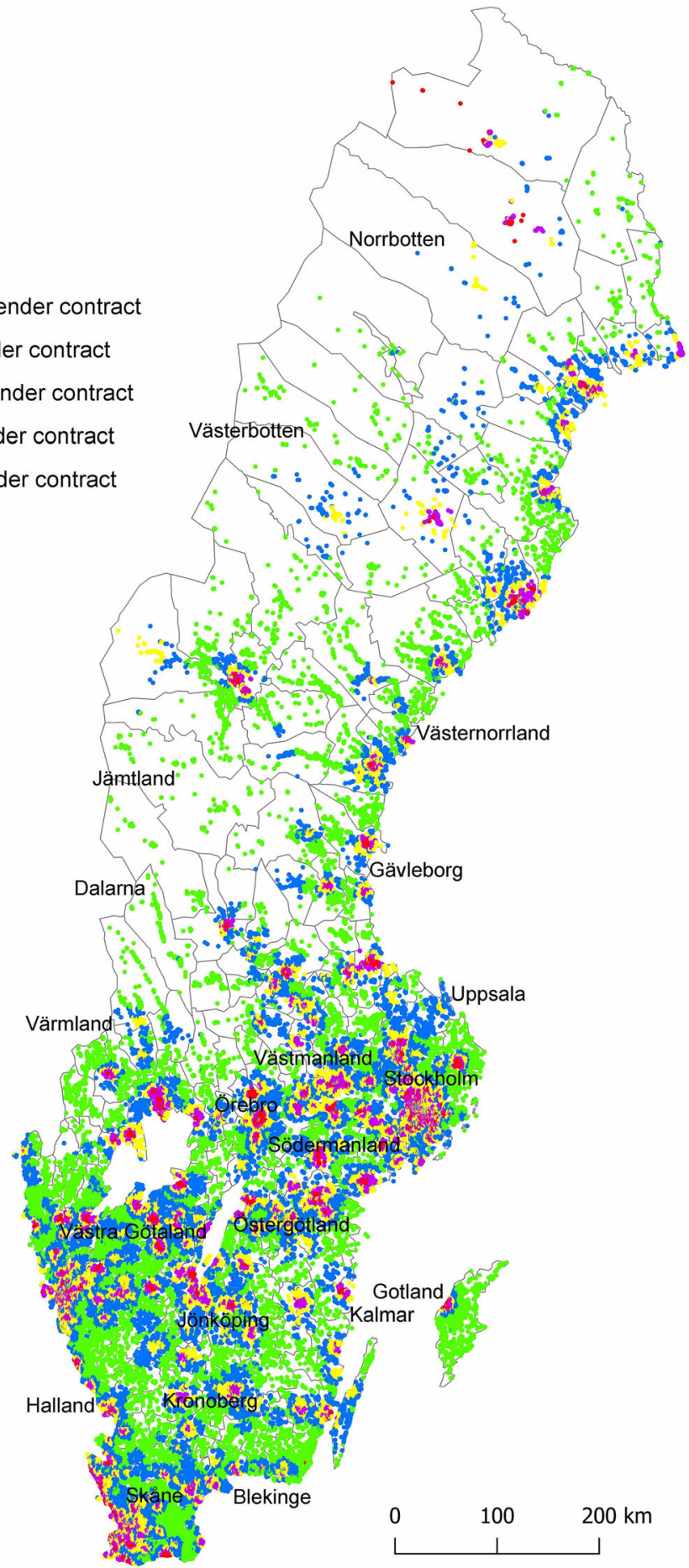

Fig. 4 Gender contract clusters 
a

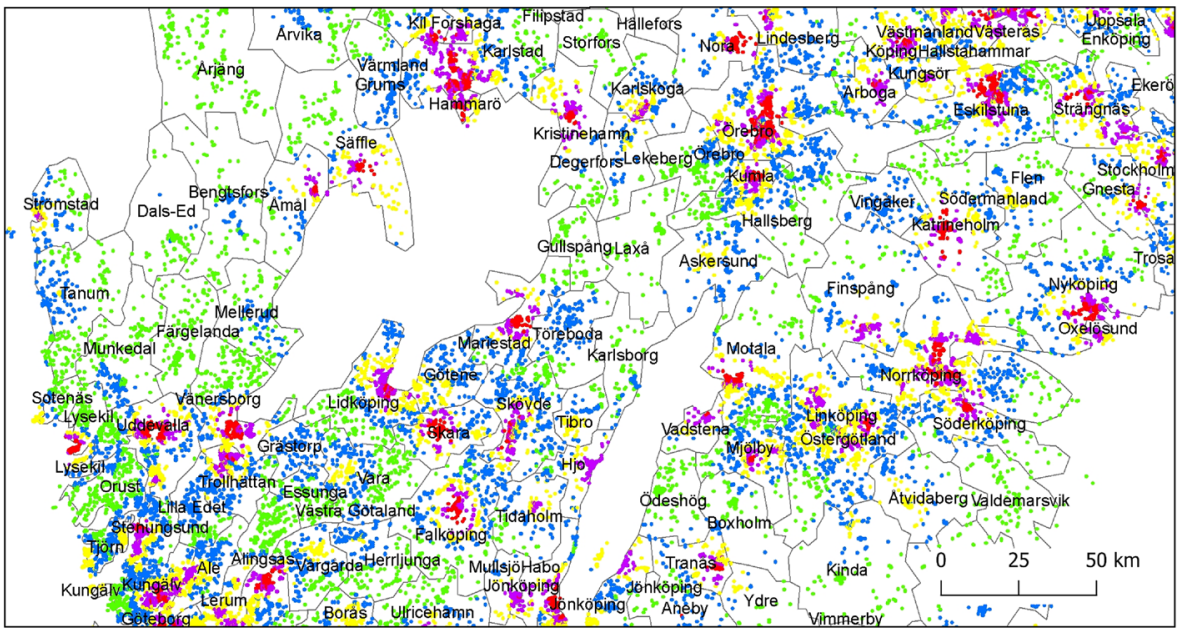

b

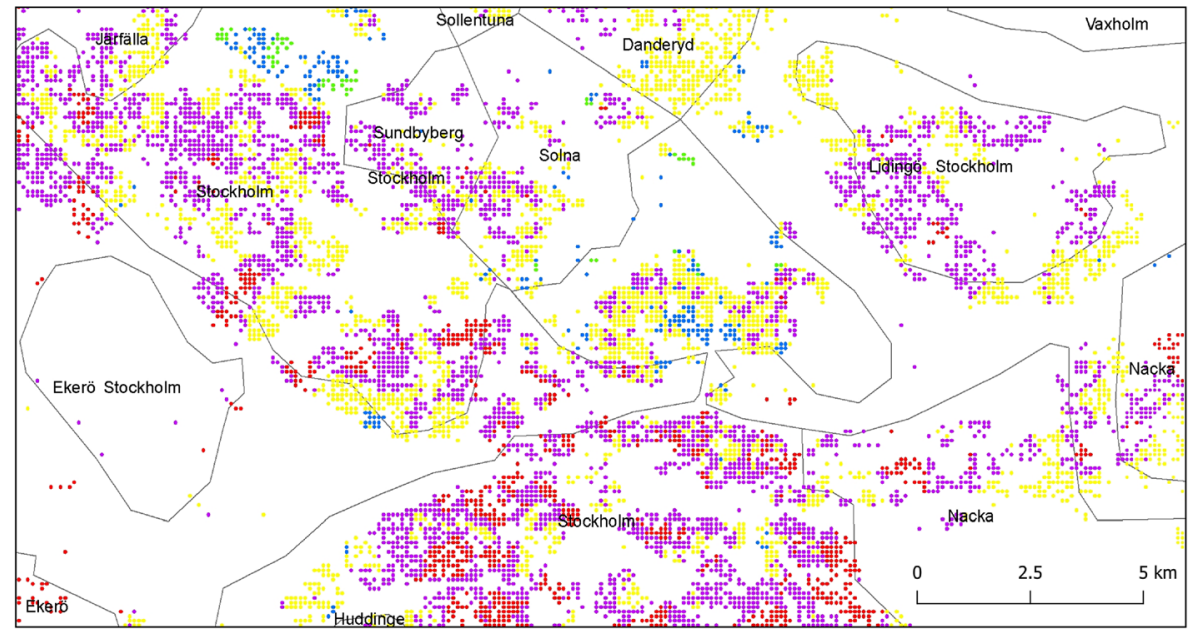

Fig. 5 Gender contract clusters zoomed in to two different regions in Sweden. a. Lakes region in Central Sweden, b. Stockholm region, N.B. for legend see fig. 4

Cluster 1 areas, red on the map, are characterized by the highest parental leave uptake by men, the highest shares of high educated and gainfully employed women, but about average shares of women with high income, and the lowest shares of young mothers. These areas are similar to Forsberg's metropolitan areas and are therefore also called metropolitan gender contracts. Surrounding almost all areas characterized by metropolitan gender contracts, we find areas that are even slightly more progressive. These are similar to metropolitan gender contract areas, but the share of women with higher incomes is considerably higher, though the share of high educated women is slightly lower than in areas with a metropolitan gender contract (see cluster 3 in Table 2, purple areas on the map). We label these areas as having progressive gender contracts, and this is the most common gender contract in Sweden. The next cluster 
(cluster 2 in Table 2, yellow areas on the map) is characterized by a slightly lower uptake of parental benefits among men, and a high share of higher educated and employed women - though lower compared to the first two clusters, and a relatively high share of women with high incomes. Many of these areas are concentrated in suburban areas, and these contracts are therefore labelled "suburban gender contracts".

The other two clusters deviate substantially from the first three. The first of these are often located inland, on commuting distance from urban areas. These contracts are characterized by an average male parental leave uptake, slightly lower levels of higher educated women and gainfully employed women compared to the national average, and substantially lower shares of women with high incomes among women (cluster 5 in Table 2, blue areas on the map). We label these "commuter gender contracts". Finally, the last cluster (cluster 4 in Table 2, green areas on the map) is labelled "traditional gender contracts", located in rural areas, with the lowest scores on all indicators related to gender contracts. In these areas, the share of fathers taking parental leave is the lowest (on average 36\%) and it is less common that women are higher educated, are gainfully employed and have higher incomes.

Figure 5 zooms in to the geographical pattern of local gender contracts for two different parts of Sweden. The first graph shows a region in Central Sweden, where the two big lakes, Vänern and Vättern, are visible in the middle. These maps show the large variation of gender contracts across space. There is not one dominant contract in any area, but instead, in all places, there are small local clusters. Even in very rural places, such as map 5a, we see clusters of metropolitan, progressive and suburban gender contracts. Gender contracts are therefore not perfectly correlated to degree of urbanisation, as there is a large variation in the type of gender contracts over towns and villages. Map 5b shows the variation in local gender contracts in the Stockholm area. The most traditional clusters, the commuter and the traditional gender contracts, are hardly to be found, except for in one of the most migrant-dense neighbourhoods in the southwest. Overall, there is a combination of the three more progressive gender contracts, with small local clusters throughout the metropolitan area.

\section{Conclusions and Discussion}

In this paper, we examined geographical variations of local gender contracts in present-day Sweden using bespoke individualized neighbourhoods. Our main motivation for the study was that previous studies had indicated a need for more detailed and nuanced analysis (Amcoff 2001; Duncan 2000; Forsberg 1998) in combination with the need for an updated study in terms of more recent data. Using data with much more geographical detail and using innovative methods, we were able to carefully operationalize local gender contracts.

Although Sweden has a very high level of gender equality, this does not mean the national gender contract is the same throughout the country. Based on fathers' parental leave uptake, the share of women who is highly educated, and the share of women who is gainfully employed, the share of women with high incomes and the share of young mothers, we mapped 5 clusters of local gender contracts: the metropolitan gender contract, the progressive gender contracts, the suburban gender contract, the commuter gender contract and the traditional gender contract. We find quite clear regional patterns, with fathers' parental leave uptake being highest in northern and eastern Sweden, but within regions there is also considerable local variation, addressing the 
first research question. Our analysis has shown that there is substantial local and regional variation in the type of gender contract characterizing neighbourhoods and areas when using individualized neighbourhoods, thereby addressing the second research question.

These local gender contracts differ from the local gender contracts found in previous studies in a number of ways. These contemporary gender contracts show more finetuned variation in gender contracts found in metropolitan areas, and in cities and towns. The present study did not find equivalent gender contracts for Forsberg's (2010) agroindustrial gender contract and company-based gender contract. In addition, there is not one dominant contract in any area, but instead, in all places, there are small local clusters of different local gender contracts. Even in the most rural places, clusters of metropolitan, progressive and normative suburban gender contracts exist beside each other. One of the reasons that previous studies concluded that larger regions had similar gender contracts is that they often only had access to large administrative units, such as municipalities. Later studies argued for the existence of several gender contracts coexisting in the same region, such as Grimsrud (2011). Our results also show the increasingly heterogeneous population living in Swedish regions.

Another major change from previous studies is that we used individualized neighbourhoods instead of using larger geographical areas. Using individualized neighbourhoods where each individual's nearest neighbours are included to form neighbourhoods, we contribute to a rapidly expanding literature that is better capable of capturing the interaction of individuals with their place of residence and to overcome the many problems related to using administratively defined areas in spatial analyses. The multiscalar approach we used allows for the measurement of gender (in)equality at different scales at the same time. Fathers' uptake of parental leave varies substantially depending on the scale of the neighbourhood or region. For the cluster analysis, a scale level was chosen that was deemed appropriate for the phenomenon of study, in combination with a visual inspection of the multiscalar maps and with knowing distances between the nearest neighbours will still allow for social interaction (Andersson et al. 2018). For further research, we recommend medium-sized k-levels that are suitable to the topic at hand and not that large so that the geographic size of neighbourhoods or areas leads to physical distances that may prevent social interaction (Mok et al. 2007).

The geographical variation in gender contracts can be seen as local differences in outcomes of negotiations between women and men, which are part of local experience and are contextualized by both individual household negotiations as well as the broader social context in which that household is situated. Our findings emphasize the importance of local variance within a gender system thus embedding gender contracts within their geographic context. The multiscalar patterns of gender contracts suggests that negotiations are locally generated and thus in order to understand gendered relations or practices, it is necessary to consider the scale of gendered practices as this choice will yield different understandings. This study has given insights into how such a choice may be made.

This study has attempted to place gender into spatial context. An improved understanding of localized patterns of gender relations leads to increased knowledge about how demographic structures, cultural traditions, historical conditions and local labour market conditions work together in creating clustered patterns of gender contracts. A description and analysis of local gender contracts shows what men and women do, but can only suggest relations that cause them (Duncan 1991). There is still value in such work, as this kind of detailed geodata has not been presented before, and these patterns 
can stimulate research questions and case studies for research on gender roles and gender inequality. Our limitations further include the type of register data we had to our disposal, for instance the variable on parental leave including not only parental leave but also child allowance and temporary parental benefits. Ideally, including the number of paid and unpaid parental leave days would give further insights. Other indicators that were not available to us may improve future research, for instance by including political representation and indicators on the segmentation of the labour market.

Using individualized neighbourhoods and applying a multiscalar approach has allowed for a more detailed and nuanced understanding of how individuals and structure are related, and how policy and other structural factors work on different scales. Knowledge about local variation in local gender contracts may be a useful resource in planning and also as input in demographic and spatial analyses. By understanding the finer variances of gender contract practices, areas may be identified that are in need of further policy and programme support.

Acknowledgments We acknowledge financial support from the Linnaeus Center on Social Policy and Family Dynamics in Europe (SPaDE) and The Swedish Research Council, registration number 349-20078701; from the Swedish Research Council (Vetenskapsrådet) via the Swedish Initiative for Research on Microdata in the Social and Medical Sciences (SIMSAM), Stockholm University SIMSAM Node for Demographic Research, grant 340-2013-5164; and from the Swedish Foundation for Humanities and Social Sciences (Riksbankens Jubileumsfond, RJ), grant registration number M18-0214:1. We thank Stefan Ene for help with the maps.

Funding Open access funding provided by Stockholm University.

\section{Compliance with Ethical Standards}

Conflicts of Interest No conflicts of interest.

Research Involving Human Participants This paper uses microdata within projects that have been ethically vetted by the Swedish Ethical Review Authority: diarienr. 2019-02826, on June 3, 2019.

\section{Informed Consent Does not apply.}

Open Access This article is licensed under a Creative Commons Attribution 4.0 International License, which permits use, sharing, adaptation, distribution and reproduction in any medium or format, as long as you give appropriate credit to the original author(s) and the source, provide a link to the Creative Commons licence, and indicate if changes were made. The images or other third party material in this article are included in the article's Creative Commons licence, unless indicated otherwise in a credit line to the material. If material is not included in the article's Creative Commons licence and your intended use is not permitted by statutory regulation or exceeds the permitted use, you will need to obtain permission directly from the copyright holder. To view a copy of this licence, visit http://creativecommons.org/licenses/by/4.0/.

\section{References}

Almqvist, A.-L., Sandberg, A., \& Dahlgren, L. (2010). The fathers and the motives. Swedish paid parental leave in a geographical perspective. Working Papers in Social Insurance 2010: 1. Stockholm: Swedish Social Insurance Agency. 
Amcoff, J. (2001). Regionala genuskontrakt i Sverige? [regional gender contracts in Sweden?] unpublished paper, Uppsala University.

Andersson, E. K., Malmberg, B., Costa, R., Sleutjes, B., Stonawski, M. J., \& de Valk, H. A. G. (2018). A comparative study of segregation patterns in Belgium, Denmark, the Netherlands and Sweden: Neighbourhood concentration and representation of non-European migrants. European Journal of Population, 34(2), 251-275.

Andersson, G., Noack, T., Seierstad, A., \& Weedon-Fekjær, H. (2006). The demographics of same-sex marriages in Norway and Sweden. Demography, 43(1), 79-98.

Åström, G., \& Hirdman, Y. (1992). Kontrakt i kris. Stockholm: Carlssons.

Bernhard, E., \& Goldscheider, F. (2006). Gender equality, parenthood attitudes, and first births in Sweden. Vienna Yearbook of Population Research, 4, 19-39.

Brandén, M., \& Haandrikman, K. (2018). Who moves to whom? Gender differences in the distance moved to a shared residence. European Journal of Population, 35(3), 435-458. https://doi.org/10.1007/s10680018-9490-4.

Duncan, S. (1991). The geography of gender divisions of labour in Britain. Transactions of the Institute of British Geographers, 16(4), 420.

Duncan, S. (1994). Theorizing differences in patriarchy. Environment and Planning A, 26(8), 1177-1194.

Duncan, S. (1995). Theorizing European gender systems. Journal of European Social Policy, 5(4), $263-284$.

Duncan, S. (2000). Introduction: Theorising comparative gender equality. In S. Duncan \& B. Pfau-Effinger (Eds.), Gender, economy and culture in the European Union (pp. 1-23). London: Routledge.

Duncan, S., \& Pfau-Effinger, B. (2000). Gender, economy and culture in the European Union. London: Routledge.

Duvander, A.-Z., \& Johansson, M. (2012). What are the effects of reforms promoting fathers' parental leave use? Journal of European Social Policy, 22(3), 319-330.

Duvander A-Z, Ferrarini, T., \& Johansson, M. (2015). Familjepolitik för alla? En ESO-rapport om föräldrapenning och jämställdhet [Family policy for all? A report on parental benefits and gender equality. En rapport till expertguppen i studier i offentlig ekonomi]. ESO 2015:5. Ministry of Finance, Stockholm.

Duvander, A-Z., \& Löfgren, N. (2020). Sweden country note. In A. Koslowski, S. Blum, I. Dobrotić, G. Kaufman and P. Moss (Eds), International review of leave policies and research 2020 (pp. 555-566). Doi: https://doi.org/10.18445/20200915-131331-0.

Duvander, A.-Z., \& Viklund, I. (2020). How long is a parental leave and for whom? An analysis of methodological and policy dimensions of leave length and division in Sweden. International Journal of Sociology and Social Policy, 40(5/6), 479-494.

Esping-Andersen, G. (1990). The three worlds of welfare capitalism. London: Polity Press.

Fisher, C. S., Stockmayer, G., Stiles, J., \& Hout, M. (2004). Distinguishing the geographical levels and social dimensions of US metropolitan segregation, 1960-2000. Demography, 41(1), 37-59.

Forsberg, G. (1997). Rulltrapperegioner och social infrastuktur [Escalator regions and social infrastructure]. In E. Sundin (Ed.), Om makt och kön. I spåren av offentliga organisationers omvandling (pp. 31-68). Statens Offentliga Utredningar 1997: 83. Stockholm: Ministry of Employment.

Forsberg, G. (1998). Regional variations in the gender contract: Gendered relations in labour markets, local politics and everyday life in Swedish regions. Innovation: The European Journal of Social Science Research, 11(2), 191-209.

Forsberg, G. (2001). The difference that space makes. A way to describe the construction of local and regional gender contracts. Norwegian Journal of Geography, 55(3), 161-165.

Forsberg, G. (2010). Gender, geography and social practice. In B. Hermelin and U. Jansson (Eds.), Placing geography. Sweden through time and Space (pp. 209-222). Stockholm: YMER, Svenska Sällskapet för Antropologi och Geografi.

Forsberg, G., Gonäs, L., \& Perrons, D. (2000). Paid work: Participation, inclusion and liberation. In S. Duncan \& B. Pfau-Effinger (Eds.), Gender, economy and culture in the European Union (pp. 27-49). London: Routledge.

Forsberg, G., Grimsrud, G. M., Jakobsen, L., Jansdotter, M., \& Vangsgraven Stubberud, K. (2006). Gränsfall: Platsens betydelse för omställning och utveckling $i$ en gränsregion [Border cases. The importance of place for adjustment and development in a border region]. Stockholm: Nordregio.

Forsberg, G., \& Lindgren, G. (2015). Regional policy, social networks and informal structures. European Urban and Regional Studies, 22(4), 368-382.

Forsberg, G., \& Stenbacka, S. (2013). Mapping gendered ruralities. European Countrysides, 1, 1-20.

Forsberg, G., \& Stenbacka, S. (2017). Creating and challenging gendered spatialities: How space affects gender contracts. Geografiska Annaler: Series B, Human Geography, 99(3), 223-237. https://doi.org/10. 1080/04353684.2017.1303269. 
Gerrard, S. (2017). Mobility practices and gender contracts: Changes in gender relations in coastal areas of Norway's high north. Nordic Journal on Law and Society, 1(1-2), 91-113.

Gil Solá, A. (2016). Constructing work travel inequalities: The role of household gender contracts. Journal of Transport Geography, 53, 32-40.

Gottfries, N. (2018). The labor market in Sweden since the 1990s. IZA World of Labor, 2018, 411.

Grimsrud, G. M. (2011). Gendered spaces on trial: The influence of regional gender contracts on in-migration of women to rural Norway. Geografiska Annaler B: Human Geography, 93B(1), 3-20.

Grubbström, A. (2012). Gender contracts in Estonian coastal farming families, 1870-1939. The History of the Family, 17(4), $434-451$.

Hedfeldt, M. (2008), Företagande kvinnor i bruksort: Arbetsliv och vardagsliv i samspel [self-employed women in small industrial towns: The interaction between work life and everyday life]. $\mathrm{PhD}$ dissertation, Örebro University.

Hennerdal, P., \& Nielsen, M. M. (2017). A multiscalar approach for identifying clusters and segregation patterns that avoids the modifiable areal unit problem. Annals of the American Association of Geographers, 107(3), 555-574.

Hirdman, Y. (1988). Gensussystemet - Reflexioner kring kvinnors sociala underordning. Tidskrift för Genusvetenskap, 3, 49-63.

Hirdman, Y. (1992). Introduktion. In G. Åström \& Y. Hirdman (Eds.), Kontrakt i kris (pp. 7-14). Stockholm: Carlsson.

Hirdman, Y. (1993). Genussystemet. Reflexioner kring kvinnors sociala underordning. In C. Ericsson (Ed.), Genus i historisk forskning (pp. 49-63). Lund: Studentlitteratur.

Hirdman, Y. (1990). Demokrati och makt i Sverige [Democracy and power in Sweden]. Statens Offentliga Utredningar 1990:44. Stockholm: SOU.

Korpi, T., \& Tåhlin, M. (2011). Changing work-life inequality in Sweden: Globalisation and other causes. In H. P. Blossfeld, S. Buchholz, D. Hofäcker, \& K. Kolb (Eds.), Globalized labour markets and social inequality in Europe (pp. 177-208). London: Palgrave Macmillan.

Kwan, M.-P. (2012). The uncertain geographic context problem. Annals of the Association of American Geographers, 102(5), 958-968.

Malmberg, B., Andersson, E. K., \& Bergsten, Z. (2014). Composite geographical context and school choice attitudes in Sweden: A study based on individually defined, scalable neighbourhoods. Annals of the Association of American Geographers, 104(4), 869-888.

McDowell, L., \& Massey, D. (1984). A woman's place? In D. Massey \& J. Allen (Eds.), Geography matters! (pp. 128-147). Cambridge: Cambridge University Press.

Mok, D., Wellman, B., \& Basu, R. (2007). Did distance matter before the internet? Interpersonal contact and support in the 1970s. Social Networks, 29(3), 430-461.

Nielsen, M. M., \& Hennerdal, P. (2017). Changes in the residential segregation of immigrants in Sweden from 1990 to 2012: Using a multi-scalar segregation measure that accounts for the modifiable areal unit problem. Applied Geography, 87, 73-84.

Nyberg, A. (2007). Lessons from the Swedish experience. In E. Hill, B. Pocock and A. Elliott (Eds.), Kids count. Better early childhood education and care in Australia (pp. 38-56). Sydney: Sydney University Press.

Openshaw, S. (1984). The modifiable areal unit problem. Norwich: Concepts and techniques in modern geography, vol. 38, GeoBooks.

Östh, J., Clark, W. A. V., \& Malmberg, B. (2015). Measuring the scale of segregation using k-nearest neighbour aggregates. Geographical Analysis, 47, 34-49.

Pfau-Effinger, B. (1994). The gender contract and part-time paid work by women - Finland and Germany compared. Environment and Planning A, 26(9), 1355-1376.

Sampson, R. J. (2012). Great American city: Chicago and the enduring neighborhood effect. Chicago: University of Chicago Press.

Scarborough, W. J., \& Sin, R. (2020). Gendered places: The dimensions of local gender norms across the United States. Gender \& Society., 34, 705-735. https://doi.org/10.1177/0891243220948220.

Sihto, T. (2018). Local childcare policy and the changing gender contract. International Journal of Sociology and Social Policy, 38(1/2), 87-102.

Stenbacka, S., Grubbström, A., \& Forsberg, G. (2018). Gendered youth strategies for inclusion in a changing society: Breaking or reproducing the local gender contract? Area, 50(4), 520-528.

Swedish Social Insurance Agency. (2013). De jämställda föräldrarna. Vad ökar sannolikheten för ett jämställt föräldrapenninguttag? [Gender equal parents. What increases the likelihood of gender equal use of parental leave?] Socialförsäkringsrapport 2013:8. Stockholm: Swedish Social Insurance Agency. 
Swedish Social Insurance Agency. (2018). Social insurance in figures 2018. Stockholm: Swedish Social Insurance Agency.

Walby, S. (1990). Theorizing patriarchy. Oxford: Basil Blackwell.

Walby, S. (1994). Methodological and theoretical issues in the comparative analysis of gender relations in Western Europe. Environment and Planning A, 26(9), 1339-1354.

Webster, N. A., \& Caretta, M. A. (2016). "Women in groups can help each and learn from each other": The role of homosocial practices within women's social networks in building local gender contracts. Multidisciplinary Journal of Gender Studies, 5(3), 1072-1097. https://doi.org/10.17583/generos.2016. 1992.

Publisher's Note Springer Nature remains neutral with regard to jurisdictional claims in published maps and institutional affiliations. 